\title{
Qa-1 Antigen
}

National Cancer Institute

\section{Source}

National Cancer Institute. Qa-1 Antigen. NCI Thesaurus. Code C17529.

A sub-type of MHC Class I 